\title{
Obestatin induced recovery of myocardial dysfunction in type 1 diabetic rats: underlying mechanisms
}

\author{
Manuela Aragno ${ }^{1 *}$, Raffaella Mastrocola ${ }^{1}$, Corrado Ghé ${ }^{2}$, Elisa Arnoletti ${ }^{2}$, Eleonora Bassino ${ }^{3}$, Giuseppe Alloatti ${ }^{3+}$
} and Giampiero Muccioli ${ }^{2+}$

\begin{abstract}
Background: The aim of this study was to investigate whether obestatin (OB), a peptide mediator encoded by the ghrelin gene exerting a protective effect in ischemic reperfused heart, is able to reduce cardiac dysfunctions in adult diabetic rats.

Methods: Diabetes was induced by STZ injection (50 mg/ $/ \mathrm{kg}$ ) in Wistar rats (DM). OB was administered $(25 \mu \mathrm{g} / \mathrm{kg}$ ) twice a day for 6 weeks. Non-diabetic (ND) rats and DM rats were distributed into four groups: untreated ND, OB-treated ND, untreated DM, OB-treated DM. Cardiac contractility and B-adrenergic response were studied on isolated papillary muscles. Phosphorylation of AMPK, Akt, ERK1/2 and GSK3ß as well B-1 adrenoreceptors levels were detected by western blot, while a-MHC was measured by RT-PCR.

Results: OB preserved papillary muscle contractility ( 85 vs 27\% of ND), ß-adrenergic response (103 vs $65 \%$ of ND), as well $B 1$-adrenoreceptors and a-MHC levels in diabetic myocardial tissue. Moreover, OB up-regulated the survival kinases Akt and ERK1/2, and enhanced AMPK and GSK3B phosphorylation. OB corrected oxidative unbalance, reduced pro-inflammatory cytokine TNF-a plasma levels, NFkB translocation and pro-fibrogenic factors expression in diabetic myocardium.

Conclusions: $O B$ displays a significant beneficial effect against the alterations of contractility and B-adrenergic response in the heart of STZ-treated diabetic rats, which was mainly associated with the ability of OB to up-regulate the transcription of $\mathrm{B1}$-adrenergic receptors and $\mathrm{a}-\mathrm{MHC}$; this protective effect was accompanied by the ability to restore oxidative balance and to promote phosphorylation/modulation of AMPK and pro-survival kinases such as Akt, ERK $1 / 2$ and GSK3ß.
\end{abstract}

Keywords: Obestatin, Diabetes, Cardiac dysfunction, Oxidative unbalance, Pro-fibrogenic and inflammatory factors, Cell survival kinases

\section{Introduction}

Obestatin (OB) is a newly discovered peptide encoded by the ghrelin gene together with acylated (AG) and unacylated ghrelin (UAG), produced in the oxyntic mucosa of the stomach [1-3]. It has been initially suggested that $\mathrm{OB}$ behaves as a physiological opponent to ghrelin, through interaction with the orphan G-protein-coupled

\footnotetext{
*Correspondence: manuela.aragno@unito.it

${ }^{\dagger}$ Equal contributors

'Department of Experimental Medicine and Oncology, University of Turin, Corso Raffaello 30, Turin 10125, Italy

Full list of author information is available at the end of the article
}

receptor 39 (GPR39) [4]. However, these findings have been questioned lately and a number of studies have failed to confirm the anorexigenic effect of obestatin [5-7] and its agonist properties on GPR39 [8,9]. Therefore, to date, some biological actions of $\mathrm{OB}$ seem to be controversial and its specific receptor remains unknown. Recent data suggest a relevant role of peptides encoded by the ghrelin gene in glucose balance and their implications for diabetes. Although the direct protective effects exerted by ghrelin gene-derived peptides on $\beta$-cells and pancreatic islets has been demonstrated in streptozotocin (STZ)-treated neonatal rats [10-13], to our knowledge,

\section{Biomed Central}


limited data exist regarding their ability to protect the myocardial tissue in adult diabetic animals, in which the ability to induce $\beta$-cell regeneration is lost.

OB plays a significant role in cardiac function in humans, both under physiological and pathological conditions. In particular, higher saliva OB levels were found in overweight patients with ischemic heart disease compared with healthy controls [14], whereas they are significantly decreased in serum of subjects with type 2 diabetes mellitus [1] and obesity [15]. Increased $\mathrm{OB}$ levels and altered ghrelin to $\mathrm{OB}$ ratio are present in chronic heart failure $(\mathrm{CHF})$ patients with cachexia [16], as well in spontaneously hypertensive rats [17]. OB improves myocardial function and reduces cell death and apoptosis of cardiomyocytes after ischemia/reperfusion $(I / R)$ in isolated rat heart [18]. These effects are probably mediated by $\mathrm{OB}$ receptors present on cardiac cells and by activation of signaling pathways included in the reperfusion injury salvage kinases (RISK), such as phosphoinositide 3-kinase (PI3K), protein kinase C (PKC) and extracellular signal regulated kinases (ERK) $1 / 2$ [18]. In type 1 diabetes, hyperglycemia is the active element leading to cardiac dysfunctions. Hyperglycemia promotes the production of reactive oxygen species (ROS) and contributes to cardiac fibrosis and contractile dysfunctions [19-23]. The protective effects exerted by $\mathrm{OB}$ against myocardial dysfunctions in ischemic-reperfused heart led us to investigate whether OB may rescue myocardial contractility and beta adrenergic response in the heart of STZ treated diabetic rats. The main results obtained in this study suggest that $O B$ displayed a beneficial effect against the reduction of contractility and $\beta$-adrenergic response, as well of $\alpha$-myosin heavy chain $(\mathrm{MHC})$ and $\beta-1$ adrenoreceptors expression in the heart of STZ-treated diabetic rats, and that the protective effect is probably related to the ability of $\mathrm{OB}$ to restore oxidative balance and to promote phosphorylation/modulation of AMPK and pro-survival kinases such as Akt, ERK1/2 and glycogen synthase kinase (GSK) $3 \beta$.

\section{Materials and methods}

\section{Cell culture}

H9c2 cardiomyoblasts, an embryonic rat heart-derived cell line, were obtained from the Istituto Zooprofilattico Sperimentale della Lombardia e dell'Emilia (Brescia, Italy) and cultured in $25 \mathrm{~cm}^{2}$ flasks with Dulbecco's Modified Eagle Medium (DMEM) containing 10\% foetal calf serum (FCS) at $37^{\circ} \mathrm{C}$ in a humidified atmosphere with 95\% $\mathrm{O}_{2}$ and $5 \% \mathrm{CO}_{2}$. Cells were starved for 24 hours in DMEM with 1\% FCS and then treated with $20 \mathrm{mM}$ metformin (Sigma-Aldrich, Milan, Italy), as positive control for AMPK phosphorylation, or $50 \mathrm{nM} \mathrm{OB}$ (rat obestatin (1-23), produced by conventional solid- phase synthesis and purified (97\%) by reverse-phase HPLC by NeoMPS, Strasbourg, France). H9c2 were then scraped, centrifugated $\left(1500 \mathrm{rpm}, 5\right.$ minutes, $\left.4^{\circ} \mathrm{C}\right)$ and lysed for total protein extraction.

\section{Animals}

Male Wistar rats (Harlan-Laboratories, Udine, Italy) weighing 200-220 g were provided with Piccioni pellet diet (no. 48, Gessate Milanese, Italy) and water ad libitum. The animals were cared for in compliance with the Local Ethical Committee and Italian Ministry of Health Guidelines (no. 86/609/EEC) and with the Principles of Laboratory Animal Care (NIH no. 85-23, revised 1985). The scientific project was supervised and approved by the Italian Ministry of Health, Rome, and by the ethical committee of the University of Torino.

\section{Animals acute treatment}

The effects of an acute treatment with $\mathrm{OB}$ or metformin were tested in a group of fifteen rats. Five rats received a daily i.p. injection of metformin $(250 \mathrm{mg} / \mathrm{kg} /$ day $)$ for three consecutive days, as indicated by Zhou et al. [24]. A second group of five rats received a single dose of $\mathrm{OB}$ by i.p. injection 1 hour before killing, following the same procedures described by Kola et al. [25] for ghrelin treatment. Five control rats received intraperitoneal injections of saline. All rats were anesthetized with $90 \mathrm{mg} / \mathrm{kg}$ of Zoletil 100 i.p. (Virbac, Carros, France) and killed by aortic exsanguinations. Hearts were removed and left ventricle was excised and rapidly homogenized to obtain protein extracts for western blotting analyses.

\section{Animals chronic treatment}

In a group of rats basal glucose level was measured by saphenous vein puncture with the Accu-Check Compact kit (Roche Diagnostics Gmbh, Mannheim, Germany). Hyperglycemia was induced in a group of rats through a single injection of streptozotocin (STZ) $(50 \mathrm{mg} / \mathrm{kg}$ b.wt) in the tail vein (diabetic, DM). A group of rats received only the vehicle (non-diabetic, ND). Three days later glucose was measured and only rats with blood glucose levels above $200 \mathrm{mg} / \mathrm{dL}$ entered the experimental protocols. ND and DM rats were distributed into four groups: untreated ND $(n=18)$ (ND-CTRL), obestatintreated ND $(n=10)(\mathrm{ND}-\mathrm{OB})$, untreated DM $(n=20)$ (DM-CTRL); obestatin-treated DM $(n=18)$ (DM-OB). $\mathrm{OB}$ was administered subcutaneously twice a day for 6 weeks, at the final dose of $25 \mu \mathrm{g} / \mathrm{kg} / 5 \mathrm{ml}$.

Two days before the sacrifice, after a fasting period of $12 \mathrm{~h}$, a $50 \%$ glucose solution at the dose of $3 \mathrm{~g} / \mathrm{kg}$ was orally administered to the rats. Glucose levels were tested $0,15,30,45,60,90,120$ and 240 min after glucose loading by saphenous vein puncture. 
Rats were sacrificed after 6 weeks. All rats were anesthetized with Zoletil 100 i.p. and killed by aortic exsanguinations. Blood was collected and the plasma isolated and placed at $-80^{\circ} \mathrm{C}$. Glucose level was immediately measured. The heart was isolated, weighed and portions of left ventricle were immediately homogenized to obtain different tissue extracts. To evaluate papillary muscles contractility and $\beta$-adrenergic response, papillary muscles were isolated from left ventricle, as described below.

\section{Plasma detection}

Triglyceride (TG), total cholesterol (TC), high-densitylipoprotein (HDL) and low density-lipoprotein (LDL) were determined in plasma by standard enzymatic procedures using reagents kits (Hospitex Diagnostics, Florence, Italy). Plasma insulin was measured by an ultrasensitive insulin enzyme-linked immunosorbent assay kit from DRG Diagnostics (Marburg, Germany). The content of TNF- $\alpha$ was determined by using a rat TNF- $\alpha$ ELISA kit (Diaclone, Besancon, France) following the manufacturer's guidelines. Each sample was tested in duplicate and averaged. Final results were calculated from the kit standards and expressed as picograms of TNF- $\alpha$ per milliliter.

\section{Protein extraction}

For cytosolic and nuclear proteins extraction, left ventricles were homogenized at $10 \%(\mathrm{w} / \mathrm{v})$ using a Potter Elvehjem homogenizer (Wheaton, NJ, USA) in a homogenization buffer [20 mM HEPES, pH 7.9, $1 \mathrm{mM} \mathrm{MgCl}_{2}, 0.5 \mathrm{mM}$ EDTA, $1 \mathrm{mM}$ EGTA, $1 \mathrm{mM}$ dithiothreitol (DTT), $0.5 \mathrm{mM}$ phenylmethylsulphonyl fluoride (PMSF), $5 \mu \mathrm{g} / \mathrm{ml}$ aprotinin, and $2.5 \mu \mathrm{g} / \mathrm{ml}$ leupeptin]. Homogenates were cleared by centrifugation at $1,000 \mathrm{~g}$ for $5 \mathrm{~min}$ at $4^{\circ} \mathrm{C}$. Supernatants were removed and centrifuged at $15,000 \mathrm{~g}$ at $4^{\circ} \mathrm{C}$ for $40 \mathrm{~min}$ to obtain the cytosolic fraction. The pelleted nuclei were resuspended in an extraction buffer [20 mM HEPES, pH 7.9, $1.5 \mathrm{mM} \mathrm{MgCl}_{2}, 0.2 \mathrm{mM}$ EDTA, 20\% (w/v) glycerol, $1 \mathrm{mM}$ EGTA, $1 \mathrm{mM}$ DTT, $0.5 \mathrm{mM}$ PMSF, $5 \mu \mathrm{g} / \mathrm{ml}$ aprotinin, and $2.5 \mu \mathrm{g} / \mathrm{ml}$ leupeptin]. The suspensions were incubated on ice for $30 \mathrm{~min}$ for high-salt extraction followed by centrifugation at $15,000 \mathrm{~g}$ for $20 \mathrm{~min}$ at $4^{\circ} \mathrm{C}$. The resulting supernatants containing nuclear proteins were carefully removed and stored.

Total extracts were obtained both from 10\% (w/v) left heart ventricle homogenates and cell lysates in RIPA buffer $[0.5 \%$ Nonidet P-40, $0.5 \%$ sodium deoxycholate, $0.1 \% \mathrm{SDS}, 10 \mathrm{mmol} / \mathrm{l}$ EDTA, and protease inhibitors]. After 40 minutes of incubation in ice, samples were cleared by centrifugation at $15,000 \mathrm{~g}$ at $4^{\circ} \mathrm{C}$ for $40 \mathrm{~min}$. Supernatants were removed and stored. Protein content was determined using the Bradford assay. Protein extracts were stored at $-80^{\circ} \mathrm{C}$ until use.

\section{Oxidative biochemical parameters}

The levels of reactive oxygen species (ROS) were measured on total extracts using the probe 2,7'dichlorofluorescin diacetate (DCFH-DA) and measured fluorimetrically [26]. Reduced and oxidized glutathione content was evaluated in cytosolic fractions following Owens's method [27]. The difference between total glutathione and reduced GSH content represents the GSSG content (expressed as $\mu \mathrm{g} / \mathrm{mg}$ prot.); the ratio between GSSG content and GSH is considered a good parameter of antioxidant status. Hydroxynonenal (HNE) concentration was also determined on cytosol fractions. After extraction, an aliquot of cytosol was injected into an HPLC (Waters Associated, Milford, MA, USA) Symmetry $\mathrm{C}_{18}$ column $(5 \mathrm{~mm}, 3.9 \times 150 \mathrm{~mm})$. The mobile phase was acetonitrile:bidistilled water $(42 \%, v / v)$. The HNE concentration was calculated by comparison with a standard solution of HNE of known concentration.

\section{Western blot}

NFkB-p65 was detected on cytosol and on nuclear extracts; AMPK, pAMPK, Akt, pAkt, ERK1/2, pERK1/2, pGSK3 $\beta, \beta 1$-adrenoreceptor and $\beta$-actin were detected on total extracts. Equal amounts of proteins $(60 \mu \mathrm{g})$ were separated on $7.5 \%$ SDS-polyacrylamide gels, then blotted on nitrocellulose membranes (Amersham Biosciences, Braunschweig, Germany). The membranes were incubated overnight with primary antibodies and reacted with appropriated peroxidase-labeled secondary antibodies (Biorad). Immunoreactive proteins were detected through the chemiluminescence assay (ECL, Amersham) and subsequent exposure to film.

Specific bands were quantified by densitometry using an analytic software (Bio-Rad, Multi-Analyst, Munchen, Germany) and the net intensity of phosphorylated proteins was normalized for the intensity of the corresponding total protein. $\beta$-actin was used as internal loading control for pGSK3 $\beta$ and cytosolic NFkB, while lamin A was used for nuclear NFkB.

\section{Semiquantitative RT-PCR}

Total RNA was extracted from left ventricle using TriPure Isolation Reagent (Roche Diagnostics). Gene transcripts for $\alpha$ - and $\beta$-MHC, $\beta 1$-adrenoreceptor, CTGF, TGF $\beta 1$ and GADPH were quantified by PCR. All experiments were performed on at least three independent cDNA preparations. PCR products were electrophoresed on $2 \%$ agarose gels and amplification products were stained with GelStar nucleic acid gel 
stain (FMC BioProducts, Rockland, ME, USA). Gels were photographed and analyzed with Kodak 1D Image Analysis software. The primer sequences were: $\alpha$-MHC forward 5' AGCCTCTCATCTCGCATCTC 3'; reverse 5' GGACCACCCATC TCACTTT 3, $\beta$-MHC forward 5' ACCGCTGAGACAGAGAATGG 3'; reverse 5' GGGTTGGCTTGGATGATTT 3', $\beta 1$-adrenoreceptor forward 5' GCCGATCTGG TCATGGGA 3'; reverse 5' GTTGTAGCAGCGGCGCG 3', CTGF forward 5' CAAGGACCG CACGTGGTT 3'; reverse 5' CCCT AGCTGCCTACCGACTGGAAGACAC 3, TGF $\beta 1$ forward 5' CTGCTGGCAA TAGCTTC CTA - 3'; reverse 5' CGAGCCTTAGTTTGGACAGGAT 3'; GAPDH forward 5' AGATCCACAACGGATACATT 3'; reverse 5' TCCCTCAAGATTGTCAGCAA 3'.

\section{Papillary muscle and contractility determination}

Papillary muscles isolated from the left ventricle were superfused with oxygenated $\left(100 \% \mathrm{O}_{2}\right)$ Tyrode solution containing (in $\mathrm{mM}$ ): $154 \mathrm{NaCl}, 4 \mathrm{KCl}, 2 \mathrm{CaCl}_{2,1}$ $\mathrm{MgCl}_{2}$, 5.5 glucose, $5 \mathrm{~N}$-(2-hydroxyethyl)-piperazineN'ethanesufonic acid (HEPES); pH 7.4 adjusted with $\mathrm{NaOH}$ ) warmed to $37^{\circ} \mathrm{C}$, and driven at constant frequency (120 beats $/ \mathrm{min}$ ). Isometric twitches were evaluated by a 60-2997 Harvard transducer, visualized on a Tektronix 2211 digital storage oscilloscope and acquired and recorded in a Power Mac computer, using the Labview Software (National Instruments Corp., Texas, USA). To study the responsiveness to $\beta$-adrenergic stimulation, after $20-30$ min equilibration, papillary muscles obtained from the different groups of animals were treated with isoproterenol (Iso, $1 \mu \mathrm{M}$ ). Preliminary studies showed that $1 \mu \mathrm{M}$ was the minimal saturating concentration of Iso.

\section{Statistical analysis}

All values were expressed as means $\pm \mathrm{SD}$, and were analyzed by one-way analysis of variance (ANOVA) followed by Bonferroni's multiple comparison test or by Newman-Keuls multiple range test, when appropriate. $P<0.05$ was considered statistically significant.

\section{Results \\ Obestatin restores papillary muscle contractility in diabetic rats}

To test whether $\mathrm{OB}$ is able to protect against the alterations of cardiac function induced by diabetic condition, contractile force developed by electrically-driven papillary muscles was evaluated both in basal conditions and after stimulation with Iso $(1 \mu \mathrm{M})$ to compare basal cardiac contractility and responsiveness to $\beta$-adrenergic stimulation among the different groups of rats (Table 1, panel A and B). As expected [28], basal contractility (panel A) was significantly weaker in papillary muscles from untreated diabetic rats compared with untreated non-diabetic muscles; this was evident not only for the maximal developed mechanical tension $\left(\mathrm{T}_{\max }\right)$, but also for the maximum rate of rise $\left(+\mathrm{dT} / \mathrm{dt}_{\max }\right)$ and the maximum rate of fall of developed mechanical tension $\left(-\mathrm{dT} / \mathrm{dt}_{\max }\right)$ (in all the cases, $\left.\mathrm{p}<0.001\right)$, while no

Table 1 A. Basal values for cardiac contractility in papillary heart muscles of untreated and OB-treated non-diabetic rats and in untreated and OB-treated diabetic rats

\begin{tabular}{|c|c|c|c|c|}
\hline \multicolumn{5}{|l|}{$\bar{A}$} \\
\hline & \multicolumn{2}{|c|}{ NON-DIABETIC } & \multicolumn{2}{|c|}{ DIABETIC } \\
\hline & CTRL $(n=6)$ & $\mathrm{OB}(n=5)$ & CTRL $(n=6)$ & $\mathrm{OB}(n=5)$ \\
\hline $\mathbf{T}_{\max }\left(\mathrm{mN} / \mathrm{mm}^{2}\right)$ & $50.3 \pm 7.7$ & $42.8 \pm 8.4$ & $13.4 \pm 6.9^{* * *}$ & $60.2 \pm 20.5^{t+\dagger}$ \\
\hline$+\mathbf{d T} / \mathbf{d t}_{\max }(\mathrm{mN} / \mathrm{s})$ & $15265 \pm 1759$ & $14043 \pm 1527$ & $5420 \pm 847^{* * *}$ & $14688 \pm 2165^{t+\dagger}$ \\
\hline$-\mathbf{d T} / \mathbf{d t}_{\max }(\mathrm{mN} / \mathrm{s})$ & $7297 \pm 874$ & $6785 \pm 645$ & $4056 \pm 953^{* * *}$ & $6333 \pm 1135^{\text {t十 }}$ \\
\hline TPT (ms) & $133.3 \pm 14.2$ & $114.5 \pm 13.6$ & $111.9 \pm 31.4$ & $149.6 \pm 9.0$ \\
\hline Duration (ms) & $379.5 \pm 48.7$ & $353.5 \pm 20.2$ & $361.7 \pm 75.4$ & $407.6 \pm 26.2$ \\
\hline \multicolumn{5}{|l|}{ B Isoproterenol (1 $\mu \mathrm{M})$} \\
\hline & \multicolumn{2}{|c|}{ NON-DIABETIC } & \multicolumn{2}{|c|}{ DIABETIC } \\
\hline & CTRL $(n=6)$ & $\mathrm{OB}(n=5)$ & CTRL $(n=6)$ & OB $(n=5)$ \\
\hline $\mathrm{T}_{\max } \%$ & $189.7 \pm 27.8$ & $197.3 \pm 48.0$ & $123.8 \pm 18.0^{* *}$ & $183.2 \pm 22.7^{\dagger \dagger}$ \\
\hline$+\mathrm{dT} / \mathrm{dt}_{\mathrm{max}} \%$ & $192.7 \pm 40.6$ & $205.0 \pm 39.2$ & $127.3 \pm 16.8^{* *}$ & $190.0 \pm 31.0^{\dagger+}$ \\
\hline$-\mathrm{dT}^{\mathrm{d}} \mathrm{dt}_{\max } \%$ & $250.3 \pm 28.1$ & $227.6 \pm 28.4$ & $126.0 \pm 14.2^{* * *}$ & $187.6 \pm 31.1^{t \dagger}$ \\
\hline TPT\% & $85.0 \pm 2.4$ & $86.6 \pm 5.9$ & $97.8 \pm 4.1^{* * *}$ & $90.8 \pm 3.3^{t+}$ \\
\hline Duration $\%$ & $83.3 \pm 3.4$ & $85.5 \pm 10.6$ & $95.6 \pm 5.8$ & $90.0 \pm 6.8$ \\
\hline
\end{tabular}

B. Effect of Iso $(1 \mu \mathrm{M})$ on cardiac contractility. Value expressed as \% variation respect to control (before Iso). Papillary muscles did not significantly differ in size among the different groups (diameter: $0.78 \pm 0.08,0.81 \pm 0.12,1.23 \pm 0.15$ and $1.18 \pm 0.09 \mathrm{~mm}$, respectively).

Values are expressed as means \pm SD. Statistical significance: ${ }^{* *} P<0.01$ vs ND-CTRL; ${ }^{* *} P<0.001$ vs ND-CTRL; †† $P<0.01$ vs DM-CTRL; ††† $P<0.001$ vs DM-CTRL. 
significant difference was found for the time to peak of mechanical tension (TPT) and duration of contraction. Treatment with OB significantly limited the reduction of contractility observed in untreated diabetic rats $(\mathrm{p}<0.001)$. However, OB treatment in non-diabetic rats did not affect per se contractile properties of papillary muscles. Moreover, papillary muscles from untreated diabetic rats showed a reduced inotropic response to $\beta$-adrenergic stimulation, which was $55 \%$ stronger in papillary muscles of untreated non-diabetic rats $(\mathrm{p}<0.01$ : Table 1, panel B). This difference was also evident for $+\mathrm{dT} / \mathrm{dt}_{\max },-\mathrm{dT} / \mathrm{dt}_{\max }$ and TPT. Treatment with OB significantly rescued the responsiveness of papillary muscles to $\beta$-adrenergic stimulation $\left(\mathrm{p}<0.01\right.$ for $\mathrm{T}_{\max }$, $+\mathrm{dT} / \mathrm{dt}_{\max },-\mathrm{dT} / \mathrm{dt}_{\max }$ and $\left.\mathrm{TPT}\right)$ in diabetic rats, while did not affect the response to Iso in non-diabetic rat. $\mathrm{OB}$ treatment did not modify heart weight and heart to body weight ratio in non-diabetic rats, while diabetic rats showed a marked decrease in heart weight compared to non-diabetics ones (Table 2). OB treatment in diabetic rats only led to a slight, not significant reduction in heart to body weight ratio compared to untreated diabetic animals. Thus, OB-treated non-diabetic rats showed a decrease $(-20 \%)$ of body weight compared to untreated non-diabetic rats. OB treatment of diabetic rats did not further reduce body weight in comparison to untreated diabetic rats (about $-44 \%$ vs CTRL) (Table 2).

\section{Obestatin promotes $\beta 1$-adrenoreceptors and $\alpha-\mathrm{MHC}$ expression recovery in diabetic myocardial tissue}

The reduced response to Iso stimulation observed in the heart of diabetic rats has been related to a limited expression of $\beta 1$-adrenoreceptors [29,30]. While $\beta 1$ adrenoreceptors protein expression showed a marked reduction in ventricular tissue of diabetic rats, a significant recovery was observed in diabetic rats treated with $\mathrm{OB}$ ( $\mathrm{p}<0.05 v s$ diabetic rats, Figure 1, panel A).

The changes reported in diabetic myocardial tissue include the switch from $\alpha$ to $\beta$ myosin isoform chains, the accumulation of fibronectin and of types I and III collagen matrix [29]. The expression of $\alpha$ and $\beta$ isoforms of the MHC protein in the left ventricle of all groups obtained by PCR analysis has been reported in Figure 1, panel B. In untreated diabetic rats we observed a decrease in $\alpha-\mathrm{MHC}$ and an increase in $\beta$-MHC isoform. OB treatment in diabetic rats partially rescued the $\alpha / \beta M H C$ ratio with respect to untreated diabetic rats. $O B$ treated non-diabetic rats did not showed any modification of $\alpha / \beta \mathrm{MHC}$ ratio. On the basis of obtained data, we looked for molecular mechanisms underlying the protective effects of $\mathrm{OB}$ against contractile impairments induced by diabetic state, by studying OB effects on oxidative stress, inflammatory response, on specific pro-survival kinases and pro-fibrogenic factors.

\section{Obestatin corrects oxidative unbalance in diabetic heart}

The levels of ROS as well as HNE, an end-product of lipid peroxidation, evaluated in cytosolic fraction of left ventricular tissue, increased significantly in untreated diabetic rats (Table 3). When OB was given to diabetic rats, ROS and HNE levels were drastically reduced if compared to untreated diabetic rats, being carried back to the values recorded in untreated non-diabetic rats. Moreover, the significant increase of GSSG/GSH ratio observed in diabetic rats further confirmed the occurrence of oxidative stress. In $\mathrm{OB}$ treated diabetic rats, this ratio was partially decreased towards values recorded in non-diabetic rats, suggesting a recovery of the GSH content (Table 3). OB treatment of non-diabetic rats did not showed per se any significant effects on oxidative parameters in comparison with untreated non-diabetic rats.

Table 2 Body weight, heart weight, heart/body weight ratio, glucose, insulin level and lipid profile in plasma of untreated and OB-treated non-diabetic rats and in untreated and OB-treated diabetic rats, evaluated at the end of the protocol time (6 weeks)

\begin{tabular}{|c|c|c|c|c|}
\hline & \multicolumn{2}{|c|}{ NON-DIABETIC } & \multicolumn{2}{|c|}{ DIABETIC } \\
\hline & CTRL $(n=12)$ & OB $(n=5)$ & CTRL $(n=14)$ & OB $(n=13)$ \\
\hline BODY WEIGHT (g) & $425 \pm 14$ & $344 \pm 12^{*}$ & $258 \pm 26^{* *}$ & $233 \pm 27^{* *}$ \\
\hline HEART WEIGHT (g) & $0.89 \pm 0.06$ & $0.88 \pm 0.08$ & $0.57 \pm 0.05^{* * *}$ & $0.52 \pm 0.05^{* * *}$ \\
\hline HEART/BODY WEIGHT (g/mg) & $2.63 \pm 0.17$ & $2.57 \pm 0.07$ & $3.20 \pm 0.22^{* *}$ & $3.09 \pm 0.21^{*}$ \\
\hline GLUCOSE (mg/dL) & $104 \pm 18$ & $99 \pm 11$ & $388 \pm 27^{* * *}$ & $372 \pm 120^{* * *}$ \\
\hline INSULIN $(\mu \mathrm{g} / \mathrm{L})$ & $0.42 \pm 0.02$ & $0.49 \pm 0.05$ & $0.18 \pm 0.04^{* * *}$ & $0.17 \pm 0.03^{* * *}$ \\
\hline TG $(\mathrm{mg} / \mathrm{dL})$ & $100.95 \pm 6.69$ & $102.26 \pm 9.11$ & $356.68 \pm 57.03^{* * *}$ & $255.09 \pm 21.84^{* *+}$ \\
\hline $\mathrm{LDL}(\mathrm{mg} / \mathrm{dL})$ & $56.78 \pm 7.46$ & $59.10 \pm 9.22$ & $169.19 \pm 14.46^{* * *}$ & $112.41 \pm 11.98^{* *+}$ \\
\hline HDL (mg/dL) & $55.99 \pm 5.50$ & $54.26 \pm 2.69$ & $25.14 \pm 3.38^{* * *}$ & $40.89 \pm 8.67^{* \dagger}$ \\
\hline TC (mg/dL) & $92.58 \pm 3.29$ & $92.91 \pm 9.57$ & $123.11 \pm 16.68^{*}$ & $104.49 \pm 5.41^{\dagger}$ \\
\hline
\end{tabular}

Values are expressed as means \pm SD. Statistical significance: ${ }^{*} P<0.05$ vs ND-CTRL; ${ }^{* *} P<0.01$ vs ND-CTRL; ${ }^{* * *} P<0.005$ vs ND-CTRL; $+P<0.05$ vs DM-CTRL. 

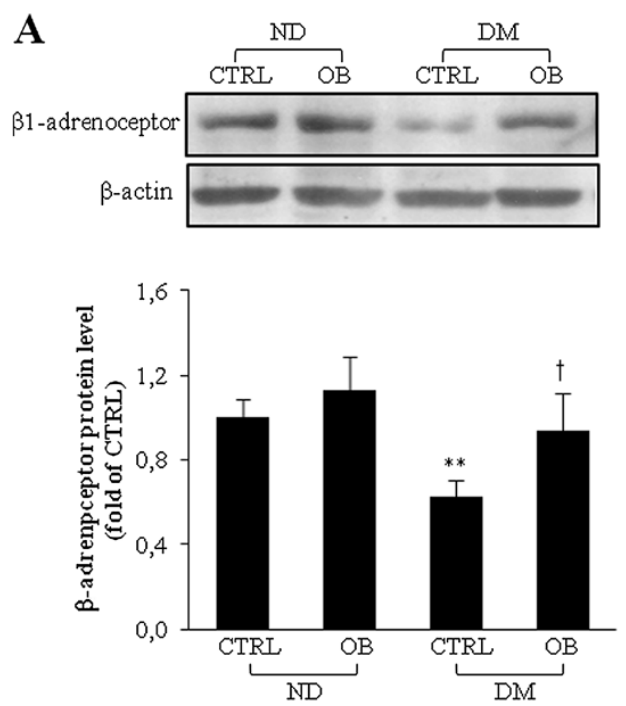
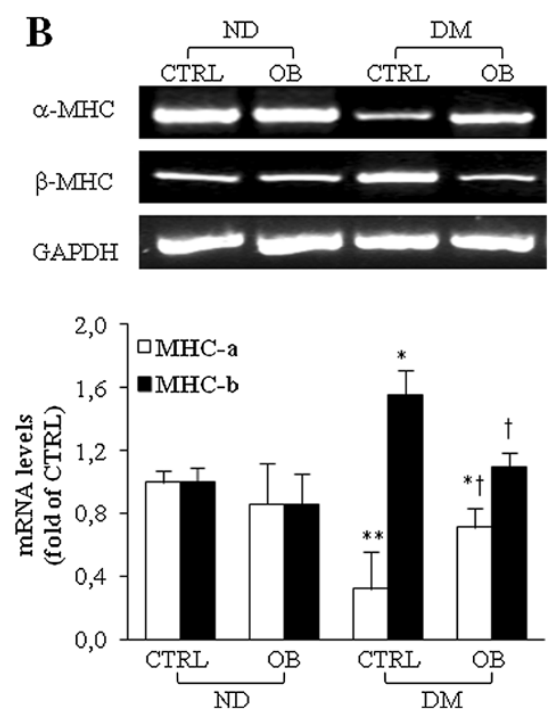

Figure 1 Representative WB analyses of $\beta 1$-adrenoreceptor (A) and semiquantitative RT-PCR analyses of $\alpha-M H C$ and $\beta$-MHC (B) expressions in left ventricular tissue RNA extracts from non-diabetic (ND) and diabetic rats (DM), treated or not with OB. Quantitative analyses are reported in the histograms, which represent the ratio of net intensity of bands with GAPDH. Data are expressed as percentage variations from the ND-CTRL value. Data are means \pm SD of $8-10$ rats per group. Statistical significance: ${ }^{*} P<0.05$ vs ND-CTRL; ** $P<0.01$ vs ND-CTRL; $+P<0.05$ DM-CTRL.

Obestatin reduces pro-inflammatory cytokine TNF- $a$ plasma levels and NFkB translocation in the diabetic myocardium

High levels of cytokines have been found in diabetic patients and several studies report the stimulatory effects of high glucose on cytokines production and on NFkB-dependent signaling activation. OB treatment in diabetic rats determined a reduction of both the proinflammatory cytokine TNF- $\alpha$ level (Figure 2, panel A) and the activation of NFkB translocation in the nucleus (Figure 2, panel B and C).

Obestatin up-regulates survival kinases Akt and ERK1/2 in diabetic left ventricular tissue

We observed a significant reduction of Akt and ERK1/2 phosphorylation levels (Figure 3, panel A and B, respectively) in untreated diabetic rats. OB treatment significantly enhanced the phosphorylation levels of both these kinases in non-diabetic rats and rescued their levels in diabetic rats.

\section{Obestatin decreases pro-fibrogenic factors expression in diabetic heart}

In our study, untreated diabetic rats showed a marked activation of the expression of CTGF and TGF- $\beta$, which represent two important pro-fibrogenic factors, responsible for up-regulated extracellular matrix production. OB caused a significant reduction in CTGF and TGF- $\beta 1$ expression respect to that observed in untreated diabetic rats, as reported in Figure 4. OB treatment in nondiabetic rats did not exert any modification in comparison with untreated non-diabetic rats.

\section{Obestatin enhances AMPK and GSK3 $\beta$ phosphorylation} In preliminary experiments to verify whether $\mathrm{OB}$ is able to directly enhance AMPK phosphorylation in $\mathrm{H} 9 \mathrm{c} 2$ myocardiocytes (Figure 5, panel A) and in acutely $\mathrm{OB}$ treated rats (Figure 5, panel $\mathrm{B}$ ), we observed that the effect of $\mathrm{OB}$ was comparable to those induced by metformin, a well-known AMPK activator [31]. In accordance with these results, we observed an up-regulation of

Table 3 Oxidative stress parameters evaluated in cardiac tissue of control, OB, STZ and STZ-treated OB rats

\begin{tabular}{ccccc}
\hline & \multicolumn{2}{c}{ NON-DIABETIC } & & \multicolumn{2}{c}{ DIABETIC } \\
\cline { 2 - 3 } & CTRL $(\boldsymbol{n}=\mathbf{1 2})$ & OB $(\boldsymbol{n}=\mathbf{6})$ & CTRL $(\boldsymbol{n}=\mathbf{1 4})$ & OB $(\boldsymbol{n}=\mathbf{1 4})$ \\
\hline ROS $($ U.F./mg prot) & $106.67 \pm 2.08$ & $106.54 \pm 15.44$ & $165.67 \pm 15.40^{*}$ & $116.43 \pm 18.02^{\dagger}$ \\
\hline GSSG/GSH (\%) & $1.60 \pm 1.00$ & $1.64 \pm 0.40$ & $8.91 \pm 2.60^{* * *}$ & $4.43 \pm 3.20^{\dagger}$ \\
\hline HNE $(\boldsymbol{\mu}$ M) & $0.80 \pm 0.08$ & $0.83 \pm 0.08$ & $1.79 \pm 0.12^{* *}$ & $1.02 \pm 0.17^{\dagger+}$ \\
\hline
\end{tabular}

Values are expressed as means \pm SD. Statistical significance: ${ }^{*} P<0.05$ vs ND-CTRL; $* * P<0.01$ vs ND-CTRL; $* * *<<0.005$ vs ND-CTRL; $+P<0.05$ vs DM-CTRL; $+\dagger P<$ 0.01 vs DM-CTRL. 

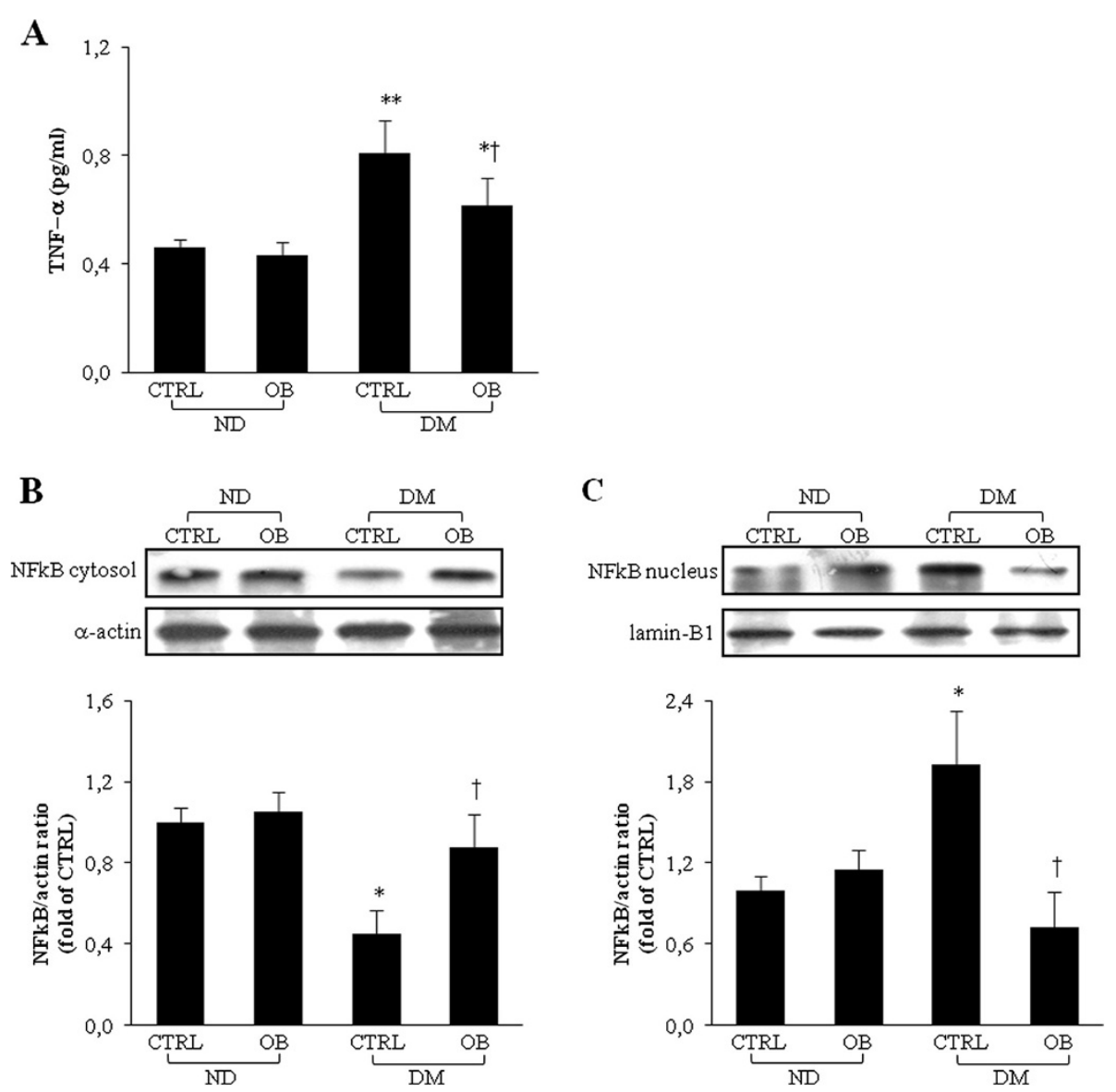

Figure 2 Representative TNFa plasma concentration determined by ELISA (A). Representative WB analyses of NFkB-p65 in cytosol (B) and in nucleus (C) obtained from left ventricular tissue from non-diabetic (ND) and diabetic rats (DM), treated or not with OB. Quantitative analyses are reported in the histograms, which represent the net intensity ratio of bands with a-actin or lamin-B1. Data are expressed as $\%$ variations from the ND-CTRL value. Data are means \pm SD of $8-10$ rats per group. Statistical significance: ${ }^{*} P<0.05$ vs ND-CTRL; ** $P<0.01$ vs ND-CTRL; $+P<0.05$ vs DM-CTRL.

AMPK in OB non-diabetic rats (Figure 5, panel C). In addition, $\mathrm{OB}$ treatment partially rescued the pAMPK level in diabetic rats, which showed a marked reduction of AMPK activity. In addition, the levels of GSK3 $\beta$, a substrate of pAkt and pAMPK activity, decreased in untreated diabetic rats (Figure 5, panel D). OB treatment in diabetic rats determined a partial recovery of pGSK3 $\beta$ levels. Taken together, our results suggested that the protective effect of $\mathrm{OB}$ against contractile dysfunction induced by chronic hyperglycemia is, at least in part, due to its ability to rescue AMPK and GSK3 $\beta$ phosphorylation.

\section{Obestatin decreases hyperlipemia but not hyperglycemia in diabetic rats}

Glycemia and insulin levels, measured after 6 weeks from STZ-injection, reflected the hyperglycemic state caused by the significant reduction of insulin. OB treatment did not determine any modification of glycemia as well as insulin plasma level in both diabetic and non- diabetic rats (Table 2). In order to find out the effect of $\mathrm{OB}$ on glucose sensitivity, we performed an oral glucose tolerance test at 6 weeks after STZ injection. Figure 6 shows the effects of oral glucose loading $(3 \mathrm{~g} / \mathrm{kg})$ in all groups. In untreated non-diabetic rats and in OB treated non-diabetic rats, glucose loading transiently increased plasma glucose levels at time $15 \mathrm{~min}$, with respect to baseline. In these groups, glycemia returned to normal values $30 \mathrm{~min}$ after glucose loading. The high glucose level already observed in diabetic rats at time 0 , was further slightly increased $15 \mathrm{~min}$ after glucose loading and remained significantly higher for up to $240 \mathrm{~min}$. The time courses describing plasma glucose trajectory in untreated and $\mathrm{OB}$ treated diabetic rats showed a not significant difference, indicating that $\mathrm{OB}$ treatment was not able to reduce the high glucose levels found in untreated diabetic rats.

OB given to non-diabetic rats did not modify lipid profile with respect to untreated non-diabetic rats. 
A
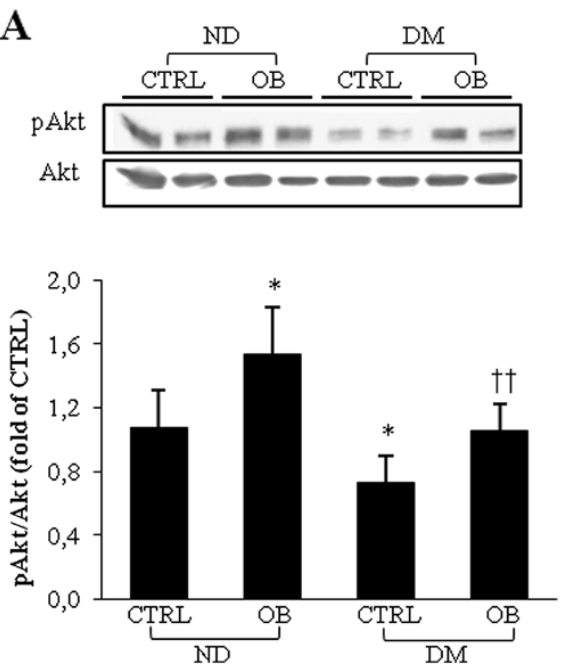

B
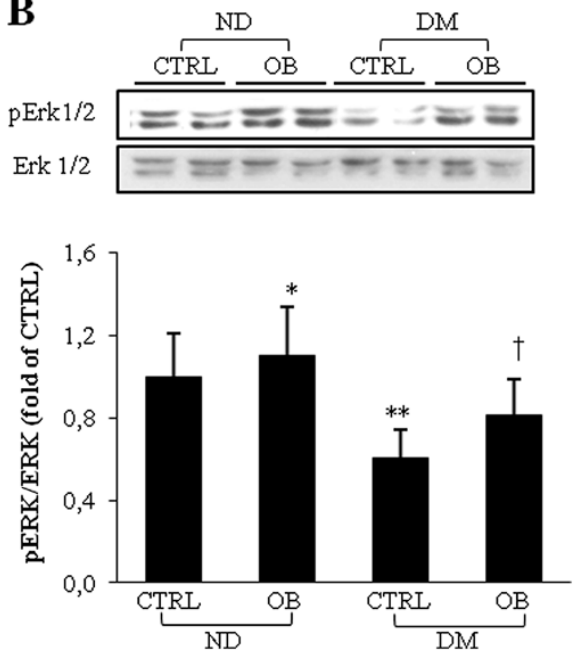

Figure 3 Representative WB analyses of pAkt (A) and pERK1/2 (B) on left ventricle total extracts from non-diabetic (ND) and diabetic rats $(\mathrm{DM})$, treated or not with $\mathrm{OB}$. Quantitative analyses are reported in the histograms, which represent the net intensity ratio of bands with total Akt or ERK1/2. Data are expressed as \% variations from the ND-CTRL value. Data are means \pm SD of 8-10 rats per group. Statistical significance: ${ }^{*} P<0.05$ vs ND-CTRL; ${ }^{* *} P<0.01$ vs ND-CTRL; $+P<0.05$ vs DM-CTRL; $+\dagger P<0.01$ vs DM-CTRL.

Untreated diabetic rats showed a significant increase in plasma lipid content (triglycerides, LDL, total cholesterol) $v s$ both untreated non-diabetic rats and $\mathrm{OB}$ treated non-diabetic rats. OB treatment in diabetic rats partially recovered lipid levels in comparison with untreated diabetic rats (Table 2). The decrease of HDL level observed in diabetic rats was partially rescued in $\mathrm{OB}$ treated diabetic rats. Thus, $\mathrm{OB}$ treatment, in nondiabetic and diabetic rats, did not exert any alteration on glycidic profile, while $\mathrm{OB}$ significantly protect against changes of lipid plasma levels of diabetic rats.

\section{Discussion}

The major new findings in this study are that: 1) OB displayed a beneficial effect against the alterations of contractility and $\beta$-adrenergic response in the heart of STZtreated diabetic rats; 2 ) the protective effect is related to the ability of $\mathrm{OB}$ to restore oxidative balance and to promote phosphorylation/modulation of AMPK and prosurvival kinases such as Akt, ERK1/2 and GSK3 $\beta$. To our knowledge, this is the first report showing that OB is able to exert a protective action in myocardial tissue affected by experimentally induced diabetes in adult animals.

$\mathrm{OB}$ is a newly discovered peptide, which derives from the ghrelin peptide precursor pre-pro-ghrelin $[1,2,4]$. Although it has been suggested that both $\mathrm{OB}$ and ghrelin participate in a complex regulatory system [32], the intracellular pathways activated by $\mathrm{OB}$ and the role it plays in physiological and in pathophysiological conditions are largely unknown. Several studies have already indicated that, in common with ghrelin and other growth hormone secretagogues, OB protects cardiac muscle against $I / R$ injury [33]. Moreover, it has been shown that ghrelin reduces oxidative stress and inhibits the production of reactive oxygen species [34,35], biological events that have been implicated in various pathologies, including hypertension [36], cardiac ischemia [37] and myocardial fibrosis [19,20,23,29]. A similar protective effect has been also reported in primary cardiomyocytes, as well as in $\mathrm{H} 9 \mathrm{c} 2$ cardiomyoblastic cell line and endothelial cells, in which both ghrelin [21] and OB [18] inhibit apoptosis induced by doxorubicin or I/R, by activating ERK1/2, PKC and PI3K/Akt dependent mechanisms. Several evidences indicate that ghrelin gene-derived peptides prevent the development of diabetes in STZ-treated newborn rats. Indeed, both ghrelin and $\mathrm{OB}$ promote regeneration of $\beta$-cells and improve glucose metabolism in STZ-treated newborn rats, granting a therapeutic potential in medical conditions associated with impaired $\beta$-cell function [10-13]. Moreover, a recent paper showed that ghrelin ameliorated the reductions in motor and sensory nerve conduction velocities and reduced oxidative stress in STZ-treated mice [38], suggesting that ghrelin gene-derived peptides could also be able to protect against dysfunction in experimentallyinduced diabetes in adult animals, in which it is likely these peptides have lost their ability to induce $\beta$-cell regeneration. In addition, ghrelin improves both the metabolic functions and the disturbed energy metabolism in the cardiac muscle of obese diabetic rats [39].

Among all diabetic complications, cardiovascular disease continues to be the primary cause of morbidity and mortality. In agreement with other studies [16,40], we previously reported that diabetic cardiomyopathy 


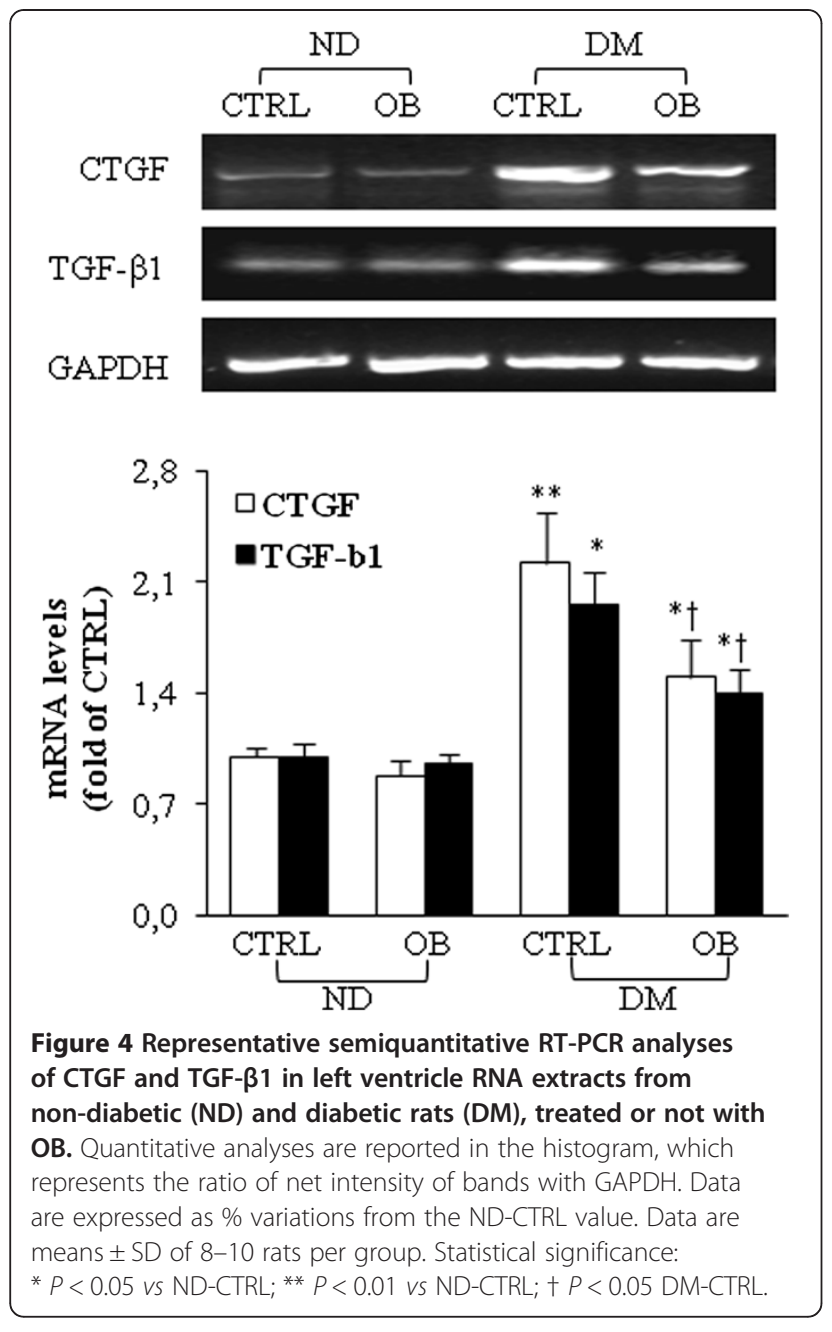

induced by chronic hyperglycemia is characterized by myocyte loss and myocardial fibrosis, which lead to decreased elasticity and impaired contractile function [29]. Moreover, the enhanced oxidative stress reduced peak contractile amplitude and maximal velocity of contraction and relaxation under basal condition, as well as the $\beta$-adrenergic response in diabetic myocardial tissue $[29,30]$.

This study demonstrates that $\mathrm{OB}$ exerts a protective effect against the derangement of contractility observed in papillary muscles from diabetic rats $(-65 \%$ of mechanical tension $v s$ control). The beneficial effect of $\mathrm{OB}$ could be due to its ability to counteract the switch of cardiac myosin heavy chain gene expression from the $\alpha$ - to the $\beta$-MHC isoform, and the increase of profibrogenic growth factors, such as TGF $\beta 1$ and CTGF, observed in diabetic myocardial tissue. In addition, $\mathrm{OB}$ was also able to restore the $\beta$-adrenergic response by promoting recovery of $\beta 1$-adrenoreceptors protein expression. The molecular mechanisms leading to myocardial dysfunction observed in diabetic myocardial tissue include an unbalance between the pro-oxidant and antioxidant compounds and increased inflammatory process, in terms of TNF- $\alpha$ plasma levels and NFkB activation. We observed that $\mathrm{OB}$ corrects oxidative unbalance and reduces inflammatory processes in diabetic myocardium, although, on the basis of our data, we do not provide a clear evidence that the initial mechanism upon which $\mathrm{OB}$ acts is related to a direct antioxidative action. We thus investigated the possible molecular mechanisms and intracellular pathway involved in the protective effect of OB. OB enhanced AMPK phosphorylation and up-regulated pro-survival kinases Akt, ERK1/2 and GSK3 $\beta$ in diabetic myocardial tissue. The ability of OB to enhance pAMPK levels in myocardial cells was confirmed by in both in vivo and in vitro models after acute administration of this peptide. Interestingly, the effects of $\mathrm{OB}$ were comparable to those induced by metformin, an anti-diabetic drug known to stimulate AMPK. AMPK has recently emerged as an important intracellular signaling pathway in the heart [31]. In the heart, AMPK is modulated by hormones such as adiponectin, leptin and ghrelin, or cytokines like TNF $\alpha$. A recent paper by Paiva [41], showing that the administration of metformin during the early reperfusion significantly enhances AMPK phosphorylation, concomitantly with the reduction of infarct size, highlighted the important role of AMPK activation in cardioprotective mechanisms. It has been proposed that AMPK may protect against reperfusion injury by increasing glucose uptake, if the potential negative consequences of increased fatty acid oxidation are not present [42]. Since ATP from glycolysis may be preferentially used to support membrane activities such as ion pumping, a shift in glucose metabolism may play an important role in cardiac contractile function, metabolic activity and calcium homeostasis under conditions of calcium overload, such as post-ischemic recovery [43] or during $\beta$-adrenergic stimulation [44].

In addition, AMPK activation has been involved in the reduction of inflammatory markers such as TNF $\alpha$ and NFkB transcription factor [45]. Together with Akt, AMPK is considered the main signaling molecule controlling cardiac functions [46]. The observed decrease of cardiac AMPK phosphorylation may therefore contribute, together with reduced Akt signaling, to the depressed myocardial contractility observed in diabetic rats. Indeed, it has been recently reported that AMPK activation may induce an enhancement of L-type calcium current $\mathrm{I}(\mathrm{Ca})$ and a prolongation of the action potential duration in cardiomyocytes [47].

Besides AMPK, OB induced phosphorylation of Akt, ERK1/2 and GSK3 $\beta$, pro-survival kinases known to exert a protective role against oxidative stress $[20,23,48]$, and proposed as integral components of a protective cascade 
A
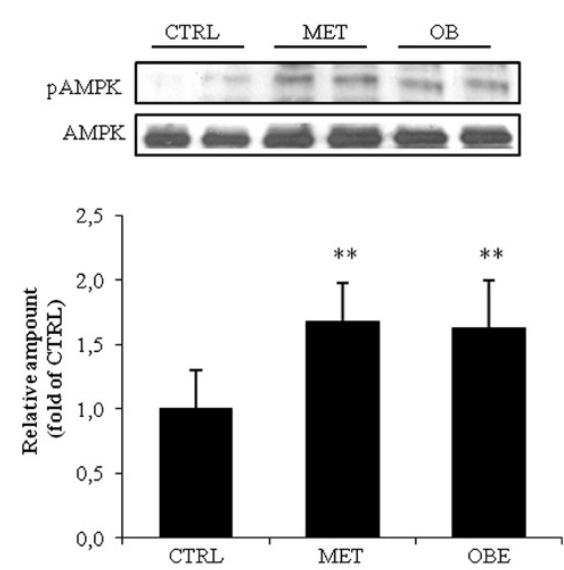

C Rat heart chronic treatment in diabetes
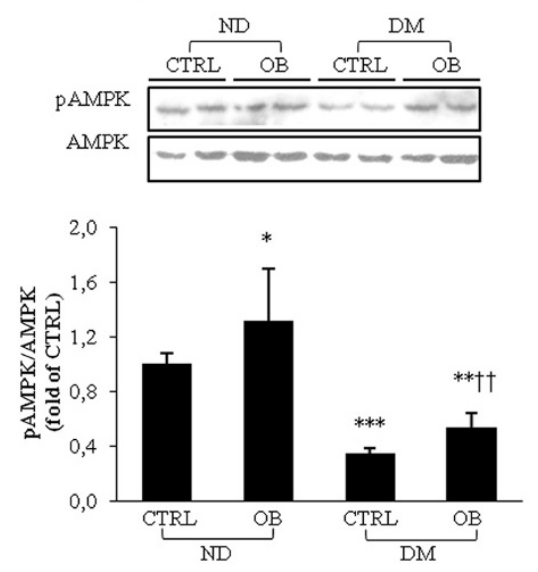

B
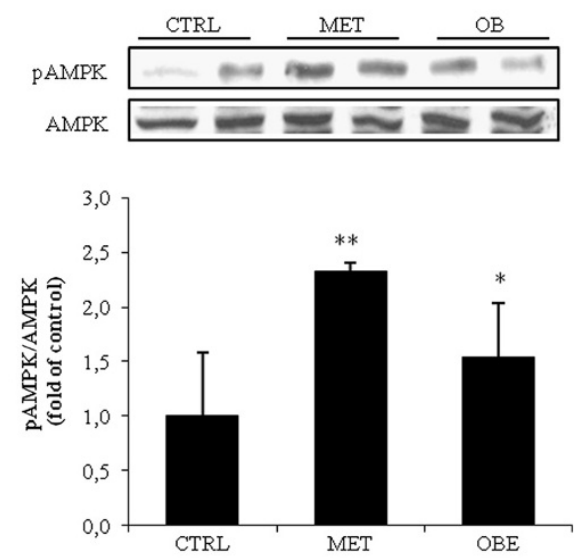

D

Rat heart chronic treatment in diabetes
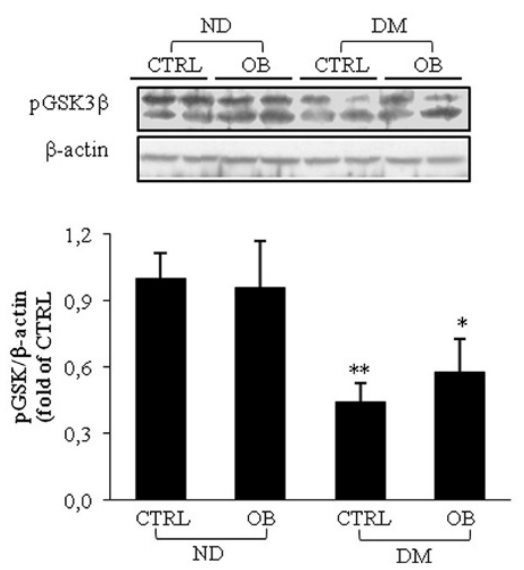

Figure 5 Representative WB analyses of pAMPK in H9c2 cells treated with metformin or obestatin (A), in left ventricle of rat subjected to acute treatment with metformin or $\mathrm{OB}(\mathrm{B})$ and in left ventricle of non-diabetic (ND) and diabetic rats (DM), treated or not with $O B$ for 6 weeks (C). Representative WB analyses of pGSK3 $\beta$ (D) in left ventricle of non-diabetic (ND) and diabetic rats (DM), treated or not with OB for 6 weeks. Quantitative analyses are reported in the histograms, which represent the net intensity ratio of bands with total AMPK or $\beta$-actin. Data are expressed as percentage variations from the ND-CTRL value. Data are means \pm SD of $8-10$ rats per group. Statistical significance: * $P<0.05$ vs ND-CTRL; ${ }^{* *} P<0.01$ vs ND-CTRL; *** $P<0.005$ vs ND-CTRL; $+P<0.05$ vs DM-CTRL; †† $P<0.01$ vs DM-CTRL.

involved in myocardial preconditioning against $\mathrm{I} / \mathrm{R}$ $[49,50]$. The involvement of these kinases in the action of $\mathrm{OB}$ has been already shown in the proliferation of human retinal pigment epithelial and gastric cancer cells [51,52], and in rodent $\beta$-cells and human pancreatic islets cell survival $[10,11]$.

Oxidative stress can trigger the opening of the mitochondrial membrane permeability transition pore (mPTP) and lead to a significant loss of mitochondrial $\mathrm{NAD}^{+}$stores and subsequent derangement of cellular energy reserves and intact cellular functions. Mitochondrial dysfunction plays an important role in the development of diabetes and insulin resistance, and proper cellular function during diabetes requires the maintenance of mitochondrial membrane potential [23]. The present study shows that $\mathrm{OB}$ also promoted phosphorylation/inactivation of GSK3 $\beta$. GSK3 $\beta$ is a substrate of multiple pro-survival protein kinases, including Akt and ERK1/2, and is therefore a step to which multiple protective signaling pathways converge [53]. Since phosphorylated GSK3 $\beta$ limits the opening of MPTP, it is reasonable to think that GSK3 $\beta$ inactivation plays a crucial role in the protective effect afforded by $\mathrm{OB}$ in diabetic myocardial tissue.

We cannot exclude, however, that the protective effect of OB may result from additional mechanisms not investigated in the present study, such as the nitric oxide (NO) pathway activation. Recent results, indeed, indicate that increased NO availability attenuates some alterations in metabolism and gene expression associated with insulin resistance induced by a high fat diet [54].

A still open question regards the earliest receptorinitiated mechanisms involved in the action of $\mathrm{OB}$. 


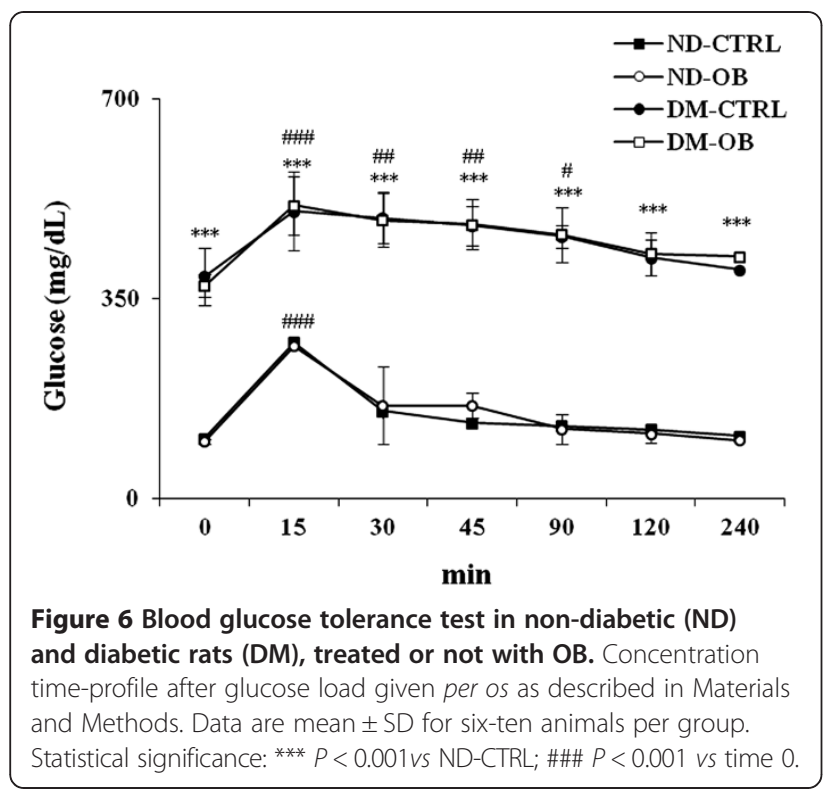

Although $\mathrm{OB}$ was initially claimed to activate the $\mathrm{G}$ protein-coupled receptor-39 (GPR39) [4], subsequent studies were unable to demonstrate binding of $\mathrm{OB}$ to GPR39 or a stimulatory function of the OB peptide on GPR39-transfected cells [8,9], and the original proposal that OB acts as a ligand of GPR39 has been retracted [28]. We have recently provided evidence that specific $\mathrm{OB}$ receptors are present in ventricular myocardial cells [18], with a receptor density and binding affinity quite close to those previously found in rodent and human pancreatic $\beta$ cells, where OB promotes cell survival and induces expression of genes involved in the regulation of $\beta$-cell mass and function $[10,11]$. In conclusion, although to date the precise role of $\mathrm{OB}$ in cardiovascular pathophysiology remains still partially unknown, the observed beneficial effect in diabetic myocardial tissue confirms the relevance of this peptide as a physiological agent exerting protective effects against cardiac dysfunction and oxidative stress, already shown in the case of ischemic/reperfused heart.

\section{Competing interests}

No conflict of interest, financial or otherwise, are declared by the authors.

\section{Authors' contribution}

Authors' contribution: experiments planning and manuscript drafting: MA, GA and GM; cell culture and animal treatment: CG, EA and RM; cardiac contractility studies: EB and GA; biochemical parameters detection, western blot and PCR: MA and RM. All author read and approved the final manuscript.

\section{Funding}

This research was supported by Turin University funding (ex-60\%), CRT Foundation 2010, RF 2010.1954 Turin Italy (MA) and Istituto Nazionale per le Ricerche Cardiovascolari (INRC), Bologna, Italy (GA).

\section{Author details}

'Department of Experimental Medicine and Oncology, University of Turin, Corso Raffaello 30, Turin 10125 , Italy. ${ }^{2}$ Department of Drug and Science
Technology, University of Turin, Via Pietro Giuria 13, Turin 10125, Italy. ${ }^{3}$ Department of Life Sciences and Systems Biology, University of Turin, Via Accademia Albertina 13, Turin 10123, Italy.

Received: 6 July 2012 Accepted: 21 September 2012

Published: 15 October 2012

\section{References}

1. Pemberton C, Richards AM: Biochemistry of ghrelin precursor peptides. Vitam Horm 2008, 77:13-30.

2. Ren AJ, Guo ZF, Wang YK, Lin L, Zheng X, Yuan WJ: Obestatin, obesity and diabetes. Peptides 2009, 30:439-444.

3. Tang SQ, Jiang QY, Zhang YL, Zhu XT, Shu G, Gao P, Feng DY, Wang XQ, Dong XY: Obestatin: its physicochemical characteristics and physiological functions. Peptides 2008, 29:639-645.

4. Zhang JV, Ren PG, Avsian-Kretchmer O, Luo CW, Rauch R, Klein C, Hsueh AJW: Obestatin, a peptide encoded by the ghrelin gene, opposes ghrelin's effects on food intake. Science 2005, 310:996-999.

5. Gourcerol H, Tache Y: Obestatin - a ghrelin associated peptide that does not hold its promise to suppress food intake and motility. Neurogastrenterol Motil 2007, 19:161-165.

6. Mondal MS, Toshinai K, Ueno H, Koshinaka K, Nakazato M: Characterization of obestatin in rat and human stomach and plasma and its lack of acute effect on feeding behaviour in rodents. J Endocrinol 2008, 198:339-346.

7. Seoane LM, Al-Massadi O, Pazos Y, Pagotto U, Casanueva FF: Central obestatin administration does not modify either spontaneous or ghrelin-induced food intake in rats. J Endocrinol Invest 2006, 29:RC13-15.

8. Holst B, Egerod KL, Schild E, Vickers SP, Cheetham S, Gerlach LO, Storiohann $L$, Stidsen CE, Jones R, Beck-Sickinger AG, Schwartz TW: GPR39 signaling is stimulated by zinc ions but not by obestatin. Endocrinology 2007, 148:13-20.

9. Lauwers E, Landuyt B, Arckens L, Schoofs L, Luyten W: Obestatin does not activate orphan G protein-coupled receptor GPR39. Biochem Biophys Res Commun 2006, 351:21-25.

10. Granata R, Settanni F, Gallo D, Trovato L, Biancone L, Cantaluppi V, Nano R, Annunziata M, Campiglia P, Arnoletti E, Ghè C, Volante M, Papotti M, Muccioli G, Ghigo E: Obestatin promotes survival of pancreatic $\beta$-cells and human islets and induces expression of genes involved in the regulation of $\beta$-cell mass and function. Diabetes 2008, 57:967-79.

11. Granata R, Volante M, Settanni F, Gauna C, Ghé C, Annunziata M, Deidda B, Gesmundo I, Abribat T, van der Lely AJ, Muccioli G, Ghigo E, Papotti M: Unacylated ghrelin and obestatin increase islet cell mass and prevent diabetes in streptozotocin-treated newborn rats. J Mol Endocrinol 2010, 45:9-17.

12. Granata R, Settanni F, Julien M, Nano R, Togliatto G, Trombetta A, Gallo D, Piemonti L, Brizzi MF, Abribat T, van Der Lely AJ, Ghigo E: Des-Acyl Ghrelin Fragments and Analogues Promote Survival of Pancreatic $\beta$-Cells and Human Pancreatic Islets and Prevent Diabetes in Streptozotocin-Treated Rats. J Med Chem 2012, 55:2585-96.

13. Irako T, Akamizu T, Hosoda H, Iwakura H, Ariyasu H, Tojo K, Tajima N, Kangawa K: Ghrelin prevents development of diabetes at adult age in streptozotocin-treated newborn rats. Diabetologia 2006, 49(6):1264-73.

14. Ozbay Y, Aydin S, Dagli AF, Akbulut M, Dagli N, Kilic N, Rahman A, Sahin I, Polat V, Ozercan HI, Arslan N, Sensoy D: Obestatin is present in saliva: alterations in obestatin and ghrelin levels of saliva and serum in ischemic heart disease. BMB Rep 2008, 41:55-61.

15. Huda MS, Durham BH, Wong SP, Deepak D, Kerrigan D, McCulloch P, Ranganath L, Pinkney J, Wilding JP: Plasma obestatin levels are lower in obese and post-gastrectomy subjects, but do not change in response to a meal. Int J Obes (Lond) 2008, 32:129-135.

16. Xin X, Ren AJ, Zheng X, Qin YW, Zhao XX, Yuan WJ, Guo ZF: Disturbance of circulating ghrelin and obestatin in chronic heart failure patients especially in those with cachexia. Peptides 2009, 30:2281-2285.

17. Li ZF, Guo ZF, Cao J, Hu JQ, Zhao XX, Xu RL, Huang XM, Qin YW, Zheng X: Plasma ghrelin and obestatin levels are increased in spontaneously hypertensive rats. Peptides 2010, 31:297-300.

18. Alloatti G, Arnoletti E, Bassino E, Penna C, Perrelli MG, Ghe C, Muccioli G: Obestatin affords cardioprotection to the ischemic-reperfused isolated rat heart and inhibits apoptosis in cultures of similarly stressed cardiomyocytes. Am J Physiol Heart Circ Physiol 2010, 299:H470-481. 
19. Asbun J, Villarreal FJ: The pathogenesis of myocardial fibrosis in the setting of diabetic cardiomyopathy. J Am Coll Cardiol 2006, 47:693-700

20. Avogaro A, de Kreutzenberg SV, Fadini GP: Oxidative stress and vascular disease in diabetes: is the dichotomization of insulin signaling still valid? Free Radic Biol Med 2008, 44:1209-1215.

21. Baldanzi G, Filigheddu N, Cutrupi S, Catapano F, Bonissoni S, Fubini A, Malan D, Baj G, Granata R, Broglio F, Papotti M, Surico N, Bussolino F, Isgaard J, Deghenghi R, Sinigaglia F, Prat M, Muccioli G, Ghigo E, Graziani A: Ghrelin and des-acyl ghrelin inhibit cell death in cardiomyocytes and endothelial cells through ERK1/2 and PI 3-kinase/Akt. J Cell Biol 2002, 159:1029-1037.

22. Fonarow GC, Srikanthan P: Diabetic cardiomyopathy. Endocrinol Metab Clin North Am 2006, 35:575-599.

23. Maiese K, Chong ZZ, Shang YC: Mechanistic insights into diabetes mellitus and oxidative stress. Curr Med Chem 2007, 14:1729-1738.

24. Zou MH, Kirkpatrick SS, Davis BJ, Nelson JS, Wiles WG 4th, Schlattner U, Neumann D, Brownlee M, Freeman MB, Goldman MH: Activation of the AMP-activated protein kinase by the anti-diabetic drug metformin in vivo. Role of mitochondrial reactive nitrogen species. J Biol Chem 2004, 279(42):43940-51.

25. Kola B, Hubina E, Tucci SA, Kirkham TC, Garcia EA, Mitchell SE, Williams LM, Hawley SA, Hardie DG, Grossman AB, Korbonits M: Cannabinoids and ghrelin have both central and peripheral metabolic and cardiac effects via AMP-activated protein kinase. J Biol Chem 2005, 280:25196-25201.

26. Ravindranath $\mathrm{V}$ : Animal models and molecular markers for cerebral ischemia-reperfusion injury in brain, Methods in Enzymology. 233rd edition. New York: Academic Press; 1994:610-619.

27. Owens CWI, Belcher RV: A colorimetric micro-method for the determination of glutathione. Biochem J 1965, 94:705-711.

28. Muccioli G, Baragli A, Granata R, Papotti M, Ghigo E: Heterogeneity of ghrelin/growth hormone secretagogue receptors. Toward the understanding of the molecular identity of novel ghrelin/GHS receptors. Neuroendocrinology 2007, 86:147-164

29. Aragno M, Mastrocola R, Alloatti G, Vercellinatto I, Bardini P, Geuna S, Catalano MG, Danni O, Boccuzzi G: Oxidative stress triggers cardiac fibrosis in the heart of diabetic rats. Endocrinology 2008, 149:380-388.

30. Gando S, Hattori Y, Akaishi Y, Nishihira J, Kanno M: Impaired contractile response to $\beta$ adrenoceptor stimulation in diabetic rat hearts: alterations in $\beta$ adrenoceptors- $G$ protein-adenylate cyclase system and phospholamban phosphorylation. J Pharmacol Exp Ther 1997, 282:475-84.

31. Steinberg GR, Kemp BE: AMPK in Health and Disease. Physiol Rev 2009, 89:1025-1078

32. Soares JB, Leite-Moreira AF: Ghrelin, des-acyl ghrelin and obestatin: Three pieces of the same puzzle. Peptides 2008, 29:1255-1270

33. Granata R, Isgaard J, Alloatti G, Ghigo E: Cardiovascular actions of ghrelin and growth hormone-releasing hormone. Exp Biol Med 2011, 236:505-514

34. El Eter $\mathrm{E}$, Al Tuwaijiri $\mathrm{A}$, Hagar $\mathrm{H}$, Arafa M: In vivo and in vitro antioxidant activity of ghrelin: attenuation of gastric ischemic injury in the rat. J Gastroenterol Hepatol 2007, 22:1791-1799.

35. Zhao H, Liu G, Wang Q, Ding L, Cai H, Jiang $H$, Xin Z: Effect of ghrelin on human endothelial cells apoptosis induced by high glucose. Biochem Biophys Res Commun 2007, 362:677-681.

36. Paravicini TM, Touyz RM: NADPH oxidases, reactive oxygen species, and hypertension: clinical implications and therapeutic possibilities. Diabetes Care 2008, 31(2):S170-180.

37. Sanada S, Komuro I, Kitakaze M: Pathophysiology of myocardia reperfusion injury: preconditioning, postconditioning, and translational aspects of protective measures. Am J Physiol Heart Circ Physiol 2011, 301: $11723-41$

38. Kyoraku I, Shiomi K, Kangawa K, Nakazato M: Ghrelin reverses experimental diabetic neuropathy in mice. Biochem Biophys Res Commun 2009, 389:405-408.

39. Hussein AA, Abdel-Aziz A, Gabr M, Hemmaid KZ: Myocardial and metabolic dysfunction in type 2 diabetic rats: impact of ghrelin. Can J Physiol Pharmacol 2012, 90:99-111.

40. Roe ND, Thomas DP, Ren J: Inhibition of NADPH oxidase alleviates experimental diabetes-induced myocardial contractile dysfunction. Diabetes Obes Metab 2011, 13:465-73.

41. Paiva MA, Gonçalves LM, Providência LA, Davidson SM, Yellon DM, Mocanu MM: Transitory activation of AMPK at reperfusion protects the ischaemic-reperfused rat myocardium against infarction. Cardiovasc Drugs Ther 2010, 24:25-32.

42. Young LH: AMP-activated protein kinase conducts the ischemic stress response orchestra. Circulation 2008, 117:832-840.

43. Nakamura K, Kusuoka H, Ambrosio G, Becker LC: Glycolysis is necessary to preserve myocardial $\mathrm{Ca} 2+$ homeostasis during beta-adrenergic stimulation. Am J Physiol 1993, 264:H670-H678.

44. Jeremy RW, Ambrosio G, Pike MM, Jacobus WE, Becker LC: The functional recovery of post-ischemic myocardium requires glycolysis during early reperfusion. J Mol Cell Cardiol 1993, 25(3):261-76.

45. Cacicedo JM, Yagihashi N, Keaney JF Jr, Ruderman NB, Ido Y: AMPK inhibits fatty acid-induced increases in NF-kappaB transactivation in cultured human umbilical vein endothelial cells. Biochem Biophys Res Commun 2004, 324:1204-1209.

46. Youn JY, Wang T, Cai H: An ezrin/calpain/PI3K/AMPK/eNOSs1179 signaling cascade mediating VEGF-dependent endothelial nitric oxide production. Circ Res 2009, 104:50-59.

47. Xiao XF, Nikolskaya A, Jaye DA, Sigg DC: Glucagon-like peptide-1 enhances cardiac L-type Ca2+ currents via activation of the cAMP-dependent protein kinase A pathway. Cardiovasc Diabetol 2011, $10: 6$.

48. Sawe N, Steinberg G, Zhao H: Dual roles of the MAPK/ERK1/2 cell signaling pathway after stroke. J Neurosci Res 2008, 86:1659-69.

49. Hausenloy DJ, Lecour S, Yellon DM: Reperfusion injury salvage kinase and survivor activating factor enhancement pro-survival signaling pathways in ischemic postconditioning: two sides of the same coin. Antioxid Redox Signal 2011, 14:893-907.

50. Murphy E, Steenbergen C: Mechanisms underlying acute protection from cardiac ischemia-reperfusion injury. Physio/ Rev 2008, 88:581-609.

51. Camina JP, Campos JF, Caminos E, Dieguez C, Casanueva FF: Obestatin mediated proliferation of human retinal pigment epithelial cells: regulatory mechanisms. J Cell Physio/ 2007, 211:1-9.

52. Pazos Y, Alvarez CJ, Camina JP, Casanueva FF: Stimulation of extracellular signal-regulated kinases and proliferation in the human gastric cancer cells KATO-III by obestatin. Growth Factors 2008, 25:373-381.

53. Juhaszova M, Zorov DB, Yaniv Y, Nuss HB, Wang S, Sollott SJ: Role of glycogen synthase kinase-3 $\beta$ in cardioprotection. Circ Res 2009, 104(11):1240-1252

54. Razny U, Kiec-Wilk B, Wator L, Polus A, Dyduch G, Solnica B, Malecki M, Tomaszewska R, Cooke JP, Dembinska-Kiec A: Increased nitric oxide availability attenuates high fat diet metabolic alterations and gene expression associated with insulin resistance. Cardiovasc Diabetol 2011, 10:68.

doi:10.1186/1475-2840-11-129

Cite this article as: Aragno et al.: Obestatin induced recovery of myocardial dysfunction in type 1 diabetic rats: underlying mechanisms. Cardiovascular Diabetology 2012 11:129.

\section{Submit your next manuscript to BioMed Central and take full advantage of:}

- Convenient online submission

- Thorough peer review

- No space constraints or color figure charges

- Immediate publication on acceptance

- Inclusion in PubMed, CAS, Scopus and Google Scholar

- Research which is freely available for redistribution 